\title{
CORRELATION BETWEEN EXPERIENCES OF ARTISTIC CREATIVE SELF-EXPRESSION AND LIFE EXPERIENCES IN CRISIS CONDITIONS
}

\begin{abstract}
Contemporary conditions determine a relationship between the quality of individual's life and individually developed creative abilities: the ability to adapt to extraordinary situations and circumstances of life, flexibility in thought and action. The studies of visual arts provide an opportunity of enriching one's experience in creative activities, at the same time facilitating the development of creative abilities. Experiences acquired earlier in life (impressions, low selfesteem and negative experiences) affect artistic creative self-expression and enhanced creative experiences, accordingly, affect the quality of life.

The aim of the article is to reveal and justify the correlations between the personal experiences of artistic creative self-expression and personal life experiences. Methods used in this study: review of scientific literature and empirical methods: observation and interviews.

Individual's creative personal experiences, acquired through artistic creative work in visual arts have a direct link with the quality of life and its improvement. While studying individual's opportunities for creative development acquiring the study content of visual arts education through studies and the opportunities for improving the quality of life, strong correlative links between experience, quality of life, creative resources and self-expression have been established.
\end{abstract}

Keywords: artistic creative self-expression; creative personal experience; creativity; crisis conditions; quality of life

\section{INTRODUCTION}

Like any time of change, the crisis brings along not only losses, but also gains. It has encouraged changes in society - the usual routines, values and human relationships have changed. Life in crisis conditions is linked to individual's quality of life and developed creative abilities: the ability to adapt to extraordinary situations and circumstances in life, flexibility in thought and action. The studies of visual arts provide an opportunity of enriching one's experience in creative activities, at the same time facilitating the development of creative abilities. Experiences acquired earlier in life (impressions, low self-esteem and negative experiences) affect artistic creative self-expression and enhanced creative experiences, accordingly, affect the quality of life. There is considerable correlation between the enhancement of experiences of artistic creative selfexpression of an individual and his life experience. Individual's creative personal experiences, acquired through artistic creative work in visual arts have a direct link with the quality of life and its improvement (uncovered individual creative potential).

\section{THE AIM OF THE STUDY}

To reveal and justify the correlations between the personal experiences of artistic creative self-expression and personal life experiences. To provide a theoretical and practical insight into 
the way, how experiences acquired throughout one's life affect artistic creative self-expression, and how creative personal experiences raise the quality of life.

\section{MATERIALS AND METHODS}

In this study the concept of human adaptability and the use of potential of originality (Sternberg, 1999); the role of creativity in human development, self-perception, quality of life (Маслоу, 1968, 1982, 2002, 2003); the role of personal resources in the creative experience (Sternberg, 2006) are analysed in the point of view of crisis solution. The concept of creativity and the concept of a healthy, self-actualising personality are becoming increasingly drawn together and may merge in a unified concept (Маслоу, 1968, 1982, 2002, 2003). It is also actual in nowadays studies about the concepts of creativity (Bennets, 2004; Villalba, 2010; Klausen, 2010). Researchers particularly (King, Gurland, 2007; Spendlove, 2007) emphasize the role of the flow phenomenon in the creative personal experience and quality of life (Csikszentmihalyi, 1996, 1999). For example, creativity and experience of a creative task: person and environment effects (King, Gurland, 2007); the role of the learning mentor in the creative cycle (Bennets, 2004).

Researchers believe that studies in visual arts are based on the socio-emotional learning movement, which stemmed from the work of humanistic psychologists such as Maslow and Rogers. For example, conceptualisation of emotion within art education - emotional dimension within a triadic schema: 1) developing emotional capacity in students to engage in a creative process (person); 2) stimulating emotional engagement through appropriate learning contexts (process); 3) facilitating the emotional interfacing with outcomes (product) - will help conceptualise the powerful interrelationship between emotion, creativity and learning (Spendlove, 2007). The development of creativity promotes Person-to-Person Learning (the concept of Carl Rogers). Person-to-Person Learning uses creativity to form rich relationships, relationships that can engage the content of education while helping students develop a positive concept of self, others, and the world (Ferch, John, Reyes, \& Ramsey, 2006).

The methods used in this research are: a review of scientific literature - the views on creativity and its influence on the quality of individual's life; empirical methods - observation, interviews, the analysis of experience's results, which allows to determine a strong correlative link between experience, quality of life, resources, creativity and self-expression in visual arts. The participants of this study were students of pedagogy and visual arts.

The empirical study is based on K.Urban's model of creativity. The model emphasizes that the elements of creativity an interacting: divergent thinking and doing; general knowledge and thinking; specific knowledge and specific skills; focusing and task commitment; motives and motivation; openness and tolerance of ambiguity (Urban, 2002). This model also includes Csikszentmihalyi, Maslow and Rogers' ideas about the development of creativity.

\section{RESULTS}

Crisis can be given two meanings - one of them denotes a dangerous, complicated, serious condition and a condition of social, political or economic instability, which contains a threat of sudden and radical change; another one treats crisis as a decisive moment, the turning point of a situation, important and painful changes during a process which is not necessarily linked to danger and loss (Dictionary of Psychology, 1999; Illustrated Dictionary of Foreign Words, 2005).

The concept of crisis is simultaneously a trend and a key word, pointing towards the typical contemporary social situation. It has already become one of the symbols of XX and 
XXI centuries: economic, political, ecological, personal and relationship crises. XX century humankind has not only experienced world wars, natural disasters and global scale economic crises, but also widely categorised science and philosophy crisis, art and Western civilisation crisis, a crisis of traditional values, humanitarian and existential crisis, and many others.

In our perception of the current crisis, society encounters both of these aspects: on the one hand, it is a period of danger and unhappiness, bringing only loss, on the other hand economic crisis is not the worst kind of crises. Like any time of change, the crisis brings along not only losses, but also gains.

Importantly, the crisis of our time has stirred fundamental changes in society, which affect consumer habits, values and human relationships. The life of each individual is being reorganised and attention is paid to the opportunities for self-actualisation, while the form of mutual relationships is altered. The re-assessment of general values has occurred and continues to progress. Most people constantly feel as though they are living in an era of instability, change and finality or on the eve of a new era. It is not easy to accept the reality for what it is. This kind of analysis can often be unpleasant and emotionally painful. Overcoming the crisis is connected to the quality of survival and the quality of life.

Life skills can be described as positive behaviour, appropriate to external factors, allowing the everyday requirements of life to be fulfilled and challenges to be accepted. The challenges of life require the individual to have developed creative abilities in order to overcome the crisis successfully. The ability to see reality free of fantasies and imagination, to find and make sense of occurrences, create solutions and react in situations, is an important one in the contemporary crisis situation. Work competence is characterised by work experience and an understanding obtained during the process of acquiring knowledge, skills and attitudes.

The aforementioned assumptions and statements originate from studies and reports in psychology claiming that in order to exist productively in the changeability and dynamics of today's world one is helped by the ability to adapt together with the potential for non-traditional approach and originality, and besides the results of work enjoying the process itself (Sternberg, 1999). Thereby, creativity itself becomes significant in individual's development, self-awareness and quality of life (Маслоу, 1968, 1982, 2002, 2003).

Creativity as a condition of human development is rooted in the diversity of individual creativity, that is, an individual is able to be creative in many ways, experiencing different phases of creative experience and taking part in them consecutively, using different personality attributes (Sternberg, 2006).

The concept of creativity and the concept of a healthy, self-actualising personality are becoming increasingly drawn together. These concepts unite such human qualities as the ability to live independently in a constantly changing world in a way allowing the inspiration of global transformations, improvisation, and capacity of facing new and unexpected situations with pleasure (Маслоу, 1968, 1982, 2002, 2003).

The humanistic viewpoint describes human and creative process as a whole, linking it to the idea of psychological well-being as a two-way process in individual's relationships with society and him/herself. The approach is rooted in the belief that each individual has a choice whereby an integral component of choice is also responsibility, leading to the idea that each individual has a development potential (Маслоу, 1968, 1982, 2002, 2003).

The concept of creativity and the concept a healthy, self-actualizing personality become drawn together and might eventually merge (Маслоу, 1968, 1982, 2002, 2003). At the centre 
of attention of the humanistic approach is the individual, his/her personality, ability to improve and develop; creativity, as an inherent natural phenomenon of human beings, arising from the primary processes of the psyche and important in the attitude of an individual towards reality, both in self-assessment and productivity. Within the context of humanistic theories, personality is characterised by consciousness, self-advancement and self-actualisation; the emphasis is laid on the uniqueness of personality - feelings, intuition, creativity and imagination. Therefore, creativity is defined as the creative abilities of a personality which may be expressed through thoughts, feelings, communication, different forms of activity, characterising the personality as a whole (Rogers, 1980). In contrast, the development of creativity is hindered by:

- avoidance of risk;

- striving towards achievements;

- stereotypes in thought and action;

- conformism;

- bowing to authority (Маслоу, 1968, 1982, 2002, 2003).

An important aspect in the link between the humanistic understanding of personality and creativity, which includes humanistic psychology, existential, phenomenological and positive psychology approaches, is empathy, the relationship of the individual with other individuals, the intensity with which the individual sees him/herself within the context of this relationship, while searching for values and the meaning of life (Frankl, 1997; May, 1965). Therefore, the concept of the dynamics of human potential, which reveals the significance of creativity in the development of the quality of life in interaction with society, has become topical (Salerno, 2005). Therefore, the ability to communicate in life with its conditions is subconsciously central to the humanistic concept of creativity. This corresponds to Maslow's opinion that a creative experience is the intense encounter of life by an individual; the function of creativity in the psyche is largely the encounter of an individual with oneself, the sense of life, self-actualisation, whereby, as a result of creative activities the individual attaches meaning to creative processes through experiencing empathy (Маслоу, 1968, 1982, 2002, 2003).

Maslow's opinions about the types of creativity and their functions fit organically with the personality theory of another representative of the humanistic school, C. Rogers, which also allows the improvement of the vision of creativity and its causes. In Rogers' opinion each individual has a biologically determined tendency towards self-actualisation, whose motivation is the continuous need to improve existence. Moreover, every individual initially possesses an instinctive and physically unerring positive self-awareness, however this is affected by social evaluation and expectations (Rogers, 1980). Similarly to Maslow, Rogers connects selfactualisation with a healthy functioning psyche, as a sign of a wholesome, functioning individual, of which the following components are characteristic:

- openness to new experiences, including the awareness of oneself in the world and experiencing emotions;

- going through existential experience in the reality of today;

- trusting physical instincts;

- creativity (Rogers, 1980).

The opinion that the main function of creativity is the development of person's inner world and self-actualisation, where the motivation for creative work is formed by the process itself, is more productive for contemporary problems. According to Maslow it concurs the creative result is the creative process itself. This substantiates the idea that the result of acquiring 
the study content of visual arts education is the experience acquired through artistic creative activities.

Within the context of positive psychology, the concept of creativity is connected to both to human values and the sense of subjective well-being, which resonates with humanistic methodology. Csíkszentmihalyi's concept of flow describes the specific psychological state of individuals during the course of creative inspiration and the creative process. Its essence is the feeling of lightness, control over what is happening, purposeful and focused concentration, pleasure in one's work (the process itself, rather than the result), a balance between the challenge offered and the abilities. His conceptual approach is based on the systematic theory, mainly geared towards creativity, inner motivation and socialisation. Therefore, when studying the phenomenon of flow, the social aspect is also of importance, the feeling of flow is one of the aspects which significantly improves the quality of individual's life. A feeling of positive and subjective well-being provides the individual with the meaning of life (Csíkszentmihalyi, 1996, 1999).

Csíkszentmihalyi emphasises seven typical indications of the feeling of flow:

1. complete immersion, focused attention on the process of concentration;

2. a feeling of ecstasy as a subjective state of being outside the normal reality of life;

3. complete inner clarity, determination;

4. certainty that the task is adequate for the ability level of the individual, does not cause stress or boredom;

5. a harmonious sense of self, free from stress, awareness of self;

6. complete concentration in the present, absorption in the process;

7. inner motivation, the reason and aim for the activity is the sense of flow, rather than the product of activity.

Csíkszentmihalyi also introduced the term of optimal experience, which he explains as the positive emotion experienced during the process and satisfaction embedded in the mind as a representation of ideal life. This means that it is the creative process of self-expression itself, rather than the wish to create a product, is what produces the motive and need for creative self-actualisation. At the moment of creation, the person forgets the past and the future and lives only in the present, being completely immersed in work, flowing together with reality (Csíkszentmihalyi, 1996, 1999). The concept of optimal experience is the theoretical basis at the foundation of organising the process of artistic creative self-expression.

Experience is formed as a result of individual's attitude towards the world, other people and him/herself. As a result of cognition the individual acquires experience and knowledge and the process of their expansion and renewal takes place. Theoretical findings emphasise the significance of the process of acquiring the study content of visual arts education for the development of personality; in the course of pedagogic process the content of artistic creative activities is simultaneously the creation of art work, artistic self-expression and the expression of content related to life, but the system's reciprocal link is actualised in man's experience.

Experience in artistic creative work in the process of self-expression can be perceived as a correlation between the individual traits of a person and external conditions, between the knowledge acquired by a person and stored in the community. Personal experience can be defined as the subjective awareness of a situation, acquired through one's own activities, learning and self-upbringing (Špona, 2001). In this connection, one might say that artistic creative self-expression in visual arts enriches the personal experience of an individual, 
because independently chosen personally significant experiences and one's inner values emotional impulses, motivation, interests, needs, values are fulfilled; individual cognition and development are supported. The individual discovering the world through artistic creative work, discovers him/herself, changes the world, while the world affects its author through his/her work, changing his/her experience, knowledge, skills and values (Столович, 1999). Accordingly, artistic work no longer has a purpose, it becomes a means for discovering the aesthetic world and oneself, expression, transformation and assessment, therefore, an enriched personal experience.

The deliberate enhancement of personal experience creates new knowledge and skills, which gives an incentive for further artistic creative work; in connection with problems it gives impulse for new achievements in life. This awareness occurs in new situations, where previous experience is not sufficient to tackle them. Wherewith, an inner conflict between experience and new external needs takes place. In studies of visual art the improvement of artistic creative experience of individuals is connected to the changes in the conditions of creative activities during the process of interaction between students and teachers.

During the process of artistic creative self-expression, the student takes part him/herself, makes his/her own choices, builds his/her own knowledge and experience and adapts to the creative process with the help of the university lecturer. The lecturer is not a passive observer, rather a leader of the artistic creative process. In order to enrich the personal experience of an individual, during the process of artistic creative self-expression the following units of value orientation levels are observed: conscious/unconscious, intellectual/emotional, individual/social and holistic nature (Briška, 2006) of artistic creative activities.

In the programmes of visual art studies, the significance of students' creative work is emphasised, therefore, the pedagogic process of artistic creative activities is organised in a way that students gain personally significant experience of free choice; personal inner values (emotional impulses, motivations, interests, needs, values) and the cognition and development of individuality. For the successful improvement of students' personal experiences, the pedagogic process of artistic creative activities is constructed to be based on the theoretical findings about the phases of creative activities: project emergence, project fruition, project implementation and project assessment (Birkerts, 1922; Bebre, 1997). Table 1 shows the connection between the phases referred to and the phases of creative self-expression in visual arts (see Table 1).

The pedagogic process of artistic creative self-expression in visual arts studies is organised in such a way as to enable effective interchange between the student and the lecturer, both external and internal resources and objective and subjective factors are incorporated in the organisation of teaching activities. External resources are formed by the teaching environment, resources with the help of which the transition from the aim to an actual result takes place. Internal resources are linked to the motivation of the lecturer and the student in the process of personal- and self-development. The effectiveness of teaching is determined by objective factors - teaching programmes, teaching aids, the lecturer's work, student's work, improvement of teaching methods, students' cognition - and subjective factors - lecturer's professionalism, the level of teaching culture and mutual relationships, as well as opportunities for creative growth.

In a process organised in this way, the student is convinced that the task is achievable, appropriate for his/her skills, does not incur stress or boredom; and complete concentration in the present (absorption in the process) and a harmonious stress-free sense of self with increased 
self-awareness are encouraged. As a result, the individual develops the creative abilities which raise the quality of life and promote the opportunities for surviving crisis conditions. It follows that the personal experience of an individual acquired through artistic creative self-expression, supports the characteristics typical of creativity: self-confidence, self-awareness, independence and disengagement; cognition of self and one's needs. The correlation between experiences of artistic creative self-expression and life activities, their causes and outcomes, is compiled in Table 2 (see Table 2).

\section{Table 1. Connections between the phases of acquiring the study content of visual arts education and creative activities}

\begin{tabular}{|c|c|}
\hline $\begin{array}{l}\text { Phases of creative activities } \\
\text { (P.Birkerts, R.Bebre) }\end{array}$ & $\begin{array}{l}\text { Phases of acquiring the study content of visual arts } \\
\text { education }\end{array}$ \\
\hline $\begin{array}{l}\text { Project emergence takes place on a wide } \\
\text { background of motivation, when impulses arise } \\
\text { to apply creative activities. }\end{array}$ & $\begin{array}{l}\text { Disengagement and development of emotions - a } \\
\text { methodical approach, the emergence of impulses, trends } \\
\text { of objectives, criteria of purposeful work, information } \\
\text { gathering, creation of ideas (sources of inspiration). }\end{array}$ \\
\hline $\begin{array}{l}\text { Project fruition (delivery, incubation) phase can } \\
\text { be varied according to duration and psychological } \\
\text { procedure. It is connected to intense awareness } \\
\text { activity. }\end{array}$ & $\begin{array}{l}\text { Purposefuldevelopmentofvisualperception-development } \\
\text { and implementation of ideas (selection of artistic resources). } \\
\text { Acquisition and use of visual aids and artistic material, } \\
\text { as well as processes - exercises of direct perception, } \\
\text { expressive techniques, analogous and intuitive techniques, } \\
\text { metamorphosis techniques (alteration, transformation, new } \\
\text { application etc), empathy (artistic abilities and skills). }\end{array}$ \\
\hline $\begin{array}{l}\text { Project implementation is a responsible phase, } \\
\text { which shows how the thoughts and observations } \\
\text { of a person transform from subjective fact to } \\
\text { other things which may be objectively perceived. } \\
\text { It is possible that during the course of work, } \\
\text { the project may change. When implementing } \\
\text { the project, surface awareness is activated, the } \\
\text { sub-conscious kicks in, awareness switches on, } \\
\text { thinking and imagination works accurately and } \\
\text { the most appropriate project implementation } \\
\text { takes place. Constant work, persistence and } \\
\text { effort is required at this phase. }\end{array}$ & $\begin{array}{l}\text { Experience in the process of visual art as a value - } \\
\text { consistent motivation for idea implementation, persistence } \\
\text { and willpower. Awareness is activated, the sub-conscious } \\
\text { kicks in, surface awareness switches on. The transformation } \\
\text { of the subjective things of an individual are implemented } \\
\text { (thoughts, application of ideas and observations) into } \\
\text { different objectively perceived things. An attitude towards } \\
\text { the acquisition of study content in visual arts education is } \\
\text { shown. The self-cognition and development of individuality. } \\
\text { Experience of creative process and arts (pleasure in work, } \\
\text { conscious and unconscious interchange). Development of } \\
\text { creative abilities. }\end{array}$ \\
\hline $\begin{array}{l}\text { Project assessment implementation and } \\
\text { improvement of the completed work, comparison } \\
\text { of results with the aims set out at the beginning. }\end{array}$ & $\begin{array}{l}\text { Implementation of self-actualisation opportunity in } \\
\text { the process of a new creation - assessment of personal } \\
\text { investment (personality) and gain (result), quality of self- } \\
\text { expression (process). Implementation of individually and } \\
\text { socially significant ideas with visual arts aids (human } \\
\text { being in the world). Motivation for a new creation, new } \\
\text { challenges, further acquisition of study content arts } \\
\text { education, personal significance thereof. Experience of free, } \\
\text { personally significant activity. Awareness of personal inner } \\
\text { values (emotional impulses, motivations, interests, needs, } \\
\text { values). Cognition and development of individuality. }\end{array}$ \\
\hline
\end{tabular}


Table 2. Causes and outcomes of the correlation between artistically creative experiences of self-expression and life activity in crisis conditions

\begin{tabular}{|c|c|c|c|}
\hline \multicolumn{4}{|c|}{ Correlation between artistically creative experiences of self-expression and life activity } \\
\hline \multirow{2}{*}{\multicolumn{2}{|c|}{\begin{tabular}{r|} 
Causes of correlation \\
Factors hindering \\
development of creativity
\end{tabular}}} & \multirow{2}{*}{\multicolumn{2}{|c|}{$\begin{array}{l}\text { Outcomes of correlation } \\
\text { Values of self-expression }\end{array}$}} \\
\hline & & & \\
\hline $\begin{array}{l}\text { Life experience } \\
\text { of an individual }\end{array}$ & $\begin{array}{l}\text { - individual's stereotypes in thoughts } \\
\text { and actions; } \\
\text { - individual's avoidance of risk; } \\
\text { - a critical mind. }\end{array}$ & $\begin{array}{l}\text { Involvement of } \\
\text { individual in the } \\
\text { artistic creative } \\
\text { process }\end{array}$ & $\begin{array}{l}\text { - } \text { freedom and disengagement; } \\
\text { - self-confidence, self- } \\
\text { awareness; } \\
\text { - cognition of self and own } \\
\text { needs. }\end{array}$ \\
\hline \multicolumn{2}{|r|}{ Development factors of creativity } & \multicolumn{2}{|r|}{ Individual's quality of life } \\
\hline $\begin{array}{l}\text { Individual's } \\
\text { experience of } \\
\text { artistic creative } \\
\text { self-expression }\end{array}$ & $\begin{array}{l}\text { - confidence that the task is } \\
\text { achievable and skill - appropriate, } \\
\text { does not cause stress or boredom; } \\
\text { - complete concentration in the } \\
\text { present (absorption in the process); } \\
\text { - harmonious sense of Self, free } \\
\text { from stress, enhanced self- } \\
\text { awareness. }\end{array}$ & $\begin{array}{l}\text { Life's activity } \\
\text { of an individual }\end{array}$ & $\begin{array}{l}\text { - self-confidence, self- } \\
\text { awareness; } \\
\text { - freedom and disengagement; } \\
\text { - cognition of self and own } \\
\text { needs. }\end{array}$ \\
\hline
\end{tabular}

As empirical experience shows, the stereotypes of thoughts and actions acquired throughout life experiences of an individual not only influence the quality of life and survival in crisis conditions, but also impede the involvement in the process of artistic creativity. Empirical methods - observation and discussions - provide a perception of this interchange.

This has been determined by the features of self-expression values, such as freedom and disengagement in the process, confidence in oneself and self-awareness, cognition of self and one's needs. Similarly, it has been determined that the components developing creativity, which raise the quality of life and promote the opportunities for the survival of an individual in crisis conditions, are encouraged through artistic creative activities.

\section{CONCLUSIONS}

Studies and theories in psychology confirm that in order to exist productively in the changeability and dynamics of today's world, the individual is helped by the ability to adapt together with the potential for a non-traditional approach and originality. Thereby, creativity becomes significant in individual's development, self-awareness and quality of life.

Artistic creative self-expression in visual arts enriches the personal experience of an individual, because independently chosen personally significant experiences and one's inner values - emotional impulses, motivation, interests, needs, values are fulfilled; individual cognition and development are supported. The individual discovering the world through artistic creative work, discovers him/herself, changes the world, while the world affects its author through his/her work, changing his/her experience, knowledge, skills and values.

While studying the opportunities for creative development in acquiring the study content of visual arts education and the opportunities for improving individual's quality of life, strong correlative links between experience, quality of life, means of creativity and self-expression have been established. 


\section{REFERENCES}

Bebre, R. (1997). Kreativitāte un skolotāja personība [Creativity and the teacher's personality]. Skolotājs, 1 , 34.-37. (in Latvian).

Bennets, C. (2004). The flight of the phoenix: Using hermeneutics to interpret the role of the mentor in the creative cycle. International Journal of Lifelong Education, 23(4), 367-383.

Birkerts, P. (1922). Daiļradīšanas psihologija I [Psychology of creative work]. Rīga: Kultūras balss. (in Latvian).

Briška, I. (2006). Aktuāls vizuālās mākslas saturs pamatskolā [Actual content of visual art at primary school]. Zinātnisko rakstu krājums Teorija praksei mūsdienu sabiedrības izglìtīîā, 3. Rīga: RPIVA, 47.-55. lpp. (in Latvian).

Csikszentmihalyi, M. (1996). Creativity, flow and the psychology of discovery and invention. New York: Harper Collins Publishers.

Csikszentmihalyi, M. (1999). Kreativität [Creativity]. Stuttgart: Klett-Cotta, 326. (in German).

Ferch, S. R., John, I. St., Reyes, R., \& Ramsey, M. (2006). Person-to-person learning: A form of creativity in education. Journal of Humanistic Counseling, Education and Development, 45, 148-164.

Frankl, V. (1997). Man's search for ultimate meaning. A revised and extended edition of The Unconscious God; with a foreword by Swanee Hunt. New York: Perseus Book Publishing.

Ilustrētā svešvārdu vārdnīca [Illustrated dictionary of foreign words] (2005). I. Andersone, I. Čerṇevska, I. Kalniņa, D. Nātiņa, R. Puriņa, L. Vjatere. Rīga: Avots (in Latvian).

King, L., Gurland, S. (2007). Creativity and experience of a creative task: Person and environment effects. Journal of Research in Personality, 41, 1252-1259.

Klausen, S. H. (2010). The notion of creativity revisited: A philosophical perspective on creativity research. Creativity Research Journal, 22(4), 347-360.

May, R. (1965). The art of counselling. Revised edition of 1989. New York: Gardner Press.

May, R. (1965). The courage to create. Reprint of 1994. WW Norton.

Psihologijas vārdnīca [Dictionary of psychology] (1999). G. Breslava redakcijā. Rīga: Mācību grāmata (in Latvian).

Roger, C. (1980). A way of being. Boston: Houghton Mifflin.

Salerno, S. (2005). SHAM: How the self-help movement made America helpless. New York: Random House.

Spendlove, D. (2007). A conceptualisation of emotion within art and design education: A creative, learning and product-orientated triadic schema. International Journal of Art \& Design Education, 26(20), 155-166.

Sternberg, R. J. (2006). The nature of creativity. Creativity Research Journal, 18(1), 87-98.

Špona, A. (2001). Audzināšanas teorija un prakse [Education theory and practice]. Rīga: RaKa. (in Latvian).

Urban, K. K. (2004). Kreativität [Creativity]. Munster: LIT, 46-51 S. (in German).

Villalba, E. (2010). Monitoring creativity at an aggregate level: A proposal for Europe. European Journal of Education, 45(2), 314-330.

Маслоу, А. (1982). Самоактуализация. Психология личности [Self-actualisation. Psychology of personality]. Тексты. Москва: Московский университет, с. 381. (in Russian).

Маслоу, А. $(2002,1968)$. По направлению к психологии былтия [Psychology in the direction of life]. Москва: ЭКСМО, c. 241. (in Russian). 
Маслоу, А. (2003). Мотивация и личнось [Motivation and personality]. Санкт-Петербург: Питер, 351 с.

Столович, Л. (1999). Философия. Эстетика. Смех [Philosophy. Aesthetics. Laughter]. Санкт-Петербург Тарту: Akademia (in Russian).

Lecturer Mg. paed. Daiga Kalēja-Gasparoviča

Riga Teacher Training and Educational Management Academy

Address: Imantas 7. linija 1, Riga, Latvia, LV-1083

Phone: +371 29418680

E-mail: daiga.kaleja@rpiva.lv 